\title{
The Use of the Internet for Corporate Reporting by Spanish Companies
}

\author{
Manuel Larrán. University of Cádiz. Spain \\ Begoña Giner. University of Valencia. Spain
}

\begin{abstract}
During the last decade there has been a profound revolution in the information technology by means of the Internet, and obviously accounting has been directly affected by this change. Although the main objective of this paper is to study the use of the Internet by Spanish companies to disclose financial information, we also discuss about the reasons of companies to use the new technologies to communicate with interested parties and its consequences. The empirical research is based on companies listed on the Madrid stock exchange, we analyse not only the information provided, but also the factors that explain the different attitudes of companies towards this vehicle for investors relationships. The results show that size is the main factor that explains not only the quantity but also the quality of financial information.
\end{abstract}

Key words: accounting, Internet, corporate reporting, Spanish companies

\footnotetext{
${ }^{1}$ This work is part of the research projects PB98-1112-C03-02 and PB98-1112-C03-03 financed by the DGESIC. We are very grateful to the useful comments received in the Parallel Session of the XI Congress of the Spanish Association of Accounting and Business (Asociación Española de Contabilidad y Administración de EmpresasAECA) (Madrid, September 2001)
} 


\section{INTRODUCTION}

The disclosure of financial information by companies, as well as its regulation, has been subject to strong critiques during the last years. This has been partially linked to the development of the new information technologies and its logical influence on the accounting practice. In our view an important aspect to be taken into account is the development of a new communication infra-structure: the Internet. The Internet increases the possibilities to manage business information, not only for internal purposes but also for external ones, and offers new ways of making commerce, offering publicity, as well as providing financial information to interested parties. In fact this new way of providing information can complement the current one, but can also be seen as a substitute in the near future. In addition it may be used to develop new channels to communicate with the users, mainly the financial community. A few data are useful to illustrate the possibilities of this communication media': in 1995 there were 44 million of Internet users, this number went up to 182 million in 1998, and it is expected to arrive at 766 million in 2005. So obviously the world appears to be closer and smaller, at least for those that use the Internet. However the distribution is still unequal around the world: $36 \%$ of the users are European, $47 \%$ are from the USA, and the other 16\% come from Asian countries.

Several factors could be taken into account to explain the demands to modify the current disclosure model, such as: 1) the strong competence of companies to obtain funds world wide, which is a consequence of the globalization process, and at the same time the fact that investors do not limit their operations to domestic markets; 2) the tendency to increase the control of companies by the stakeholders, as the publication of voluntary codes of conduct suggest; 3 ) the shortage of information in the current model about important aspects that are crucial to understand companies' risks and potentials, such as intangible assets (intellectual capital, structural capital and relational capital), as well as environmental issues. In the document "The 21st Century Annual Report" (ICAEW, 1998) it is argued that the periodic financial information has to be replaced by a continuous reporting system with different segments of information that will have to be updated at

\footnotetext{
${ }^{2}$ See: http://www.isoc.org
} 
different time intervals. This implies that the idea of annual and intermediate information will be soon considered obsolete. And it appears obvious that the Internet can play a key role in this development. Another interesting research that provides a strong critique about the current type of financial information is Beattie (1999). After some questionnaires and interviews to the accounting users, she concludes that it is necessary to change the current model, and suggests that the financial information has to be on the net in order to make easier the access to all potential interested parties. As a conclusion it can be stated that the new information demands, mainly referred to additional information and more timely information, will be linked to the development of the new information technologies. In fact according to the document Business Reporting on the Internet, that was prepared by a group of experts and commissioned by IASC in 1998, the web will be used as the primary information dissemination channel, with the print-based mode as a secondary channel in about five years time (Lymer et al. 1999, 4).

The purpose of this paper is to give some additional arguments to the debate by focusing on how accounting information, and companies, are affected by the new technologies, particularly by the Internet. To this end, in section two we will consider some reasons to explain why companies voluntarily use the Internet to disclose financial information, as well as the effects of the disclosure. Next we will refer to several papers that have analysed the information disclosed by companies in different countries. The fourth section is devoted to our empirical analysis focused on the Spanish companies quoted on the Madrid continuo market. Last section includes the conclusions.

\section{REASONS AND EFFECTS OF THE USE OF THE NEW INFORMATION TECHNOLOGIES}

As the document on "Electronic Distribution of Business Reporting Information" sustains, a company may be interested in disclosing financial information through the Internet by several reasons (FASB, 2000, 1):

"Reducing the cost of and time to distribute information.

Communicating with previously unidentified consumers of information. 
Supplementing traditional disclosure practices.

Increasing the amount and type of data disclosed.

Improving access to potential investors for small companies".

When the information is electronically disseminated becomes immediately available to those connected to the Internet at practically no cost. In practice, it can be said that there are no additional costs for the company, and no costs for the users. The information included in the web sites is (or should be) the easiest available information, so talking about financial information, it is obvious that companies can distribute their financial reports as soon as they have it, so without any lag. There are no delays because printing, editing, faxing or mailing the reports. When the company has its own web site it is very easy to include any kind of information, and to update it when necessary. In addition the additional cost of doing these things is practically non existent, and independent of the number of users of the information. In other words the marginal cost per user is zero.

Both aspects no cost and timeliness contribute to increase the value of accounting information, particularly the second aspect is a well known requirement of accounting data according to the conceptual frameworks of FASB and IASB, among others ${ }^{3}$. As the FASB sustains "The availability of more timely and relevant information should help increase the efficiency of capital markets" $(2000,2)$. Another important aspect that affects market efficiency is the cost of information, the lower the cost, the more investors will take part in the market, and the higher the efficiency.

The second motive indicated by the FASB relates to the potential users of the Internet. It is true that during the last years the number of investors that invest in the stock exchanges in a direct way has been increasing. At the moment we do not know if they use or not accounting information to take their decisions, but obviously they are potential users. As long as companies want to contact with investors, it seems logical they include the financial information in their web sites to provide

\footnotetext{
${ }^{3}$ In order to increase timeliness it would be convenient to make changes in auditing. Therefore it would be probably convenient to focus more on the procedures of the accounting system, than in the last product, the annual accounts.
} 
them with useful information. Although as many studies indicate, nowadays medium and small companies are not using the Internet to this purpose, it seems that this way of finding investors can be specially interesting for them

The other reasons to disseminate financial information through the Internet are linked to the desire to provide more information to third parties. The web site is a useful tool to centralize all the information about the company, and to communicate with investors, customers, and other stakeholders. It helps to give visibility to the company and to facilitate the communication with the investors relations and finance departments. In other words companies tend to employ this new instrument to give additional information, but why? Companies behaviour towards the disclosure of voluntary information may be explained by using different economic theories, such as: agency, signalling and proprietary costs , as well as political costs theory. Although some of the previous empirical research about the existence of financial information in the web sites has taken into account these theoretical arguments, normally they have not been explicitly tested. However they will be considered in our empirical research. Agency theory sustains that the more levered companies disclose more information to increase the confidence of the debtholders, so information is used a mechanism to control managers (Jensen and Meckling, 1976). It could be also argued that those companies directed by managers, who do not have company shares, tend to provide more information to increase their credibility. Signalling theory implies that voluntary information is used by good companies as a mechanism to reduce the adverse selection problem , that reduces the value of these companies compared with other less valuable companies. In this context the manager's decision to disclose information depends on his/her opinion about its effect on the users' decisions, which depends on the relevance of the information, and the companies' quality (Wagenhofer, 1990). As far as the proprietary costs is concerned, it is true that the disclosure of certain type of information could produce competitive costs, as it is normally sustained when talking about segmental information (Edwards and Smith 1996). In addition we also mentioned that the production and dissemination costs derived from the information distributed through the net is practically non existent. Finally it is assumed that those companies which are politically more visible, so more subject to political costs, could use the information to avoid these risks (Holthausen and Leftwich, 1983). 
As far as the effects of the use of the new technologies one big potential advantage due to these changes is the increase in market efficiency. This will be produced by the increase in the number of market participants, and the increase in information provided by companies to the market at a very low cost, o even without any cost. The availability of more timely information about companies at no cost will make the market more efficient. If "new" information" is disclosed to the market, stock prices will be better valued, so companies can influence their prices by disclosing new aspects about their performance, financial situation, prospects and so on. In addition the higher the number of users, due to the availability of information in the net, the lower the informational advantages of sophisticated users, such as financial intermediaries, over the rest. All these aspects will contribute to the efficiency of the stock markets.

As far as the agency theory is referred, it has to be considered that the agency costs of the various relationships that form the company will decrease as a consequence of the amount of information. In addition the reduction in the information asymmetry among principals and agents (shareholders and managers, as well as debtholders and managers) will reduce the cost of capital of the company.

In front of these advantages of the electronic information, one has to consider a potential disadvantage, the risk of increasing the legal demands against the company. This problem has been clearly mentioned by FASB $(2000,55)$. The inclusion of forward-looking statements, or the inclusion of analysts' comments (specially the favourable ones) or the existence of links to analysts' web sites, without disclaimers or with deficient disclaimers, can confuse users, so they could take legal actions, particularly if they have losses as consequence of the information disclosed by the company, or by third parties linked to the company's web site. The FASB also mentions other potential causes of legal risks, such as: inclusion of incomplete financial statements (without part of the notes to the accounts, or without a specific financial statement), and posting of transcripts of speeches or conference calls, without appropriate disclaimers. In addition we appreciate another potential problem, the inclusion of the auditing report with non-complete financial

\footnotetext{
4 "New" information is a redundant expression, because only if something is new is considered information, as long it is able to change users' decisions.
} 
statements, or the exclusion of the auditing report in some circumstances. It is certainly an area that should be regulated carefully, in order to avoid the discretion of companies to disclose part of the annual accounts. Finally some also argue that the existence of more information about the company might imply an excess of information that could undermine the user capacity to process and use it. This could affect mainly to the non sophisticated users. In our view it is an empirical question to discover if this last concern is reasonable or not.

\section{PREVIOUS EMPIRICAL RESEARCH}

There are a number of studies that make a descriptive analysis about the type of financial information that companies disclose through the Internet. Table 1 provides a summary of the main aspects of these studies. However in order to value the results it is necessary to take into account that the studies are normally referred to one or two years before the publication of the research, and they have been normally done by analysing the content of the company web site in a very short period, one month, or even one day, as in the research prepared by the FASB. Although most of the papers are referred to the USA and the UK, Spain has also been frequently studied. The general conclusion is that the use of the Internet has been gradually increasing along the years, specially in those countries with a developed capital market, although, with the probable exception of the US companies, it is not possible to talk about massive use. In addition as the studies consider listed companies, and generally only large companies are included in the samples, it is not possible to make assumptions about the behaviour of other companies. Most of the studies are country specific (with the exception of Debreceny and Gray 1999, Deller et al. 1999, and Lymer et al. 1999), and their results are not directly comparable. In fact they employ a very similar methodology, but neither the items considered are equal, nor the time period is the same. Another important aspect to be mentioned is the difference in the content and frequency of updating the information in different companies/countries.

The working group commissioned by IASC, and directed by Andrew Lymer (1999), analysed the use of the web to disclose financial information by the largest 30 companies included in the Dow Jones Global Index in 22 countries. According to the results of the analysis, $86 \%$ of the companies have web site, but the 
penetration ratio widely varies from $100 \%$ in Germany, France, Sweden, Canada and the USA, to $43 \%$ in Malaysia, or 53\% in Chile. In the UK it is $97 \%, 90 \%$ in the Netherlands, $83 \%$ in Italy, $80 \%$ in Norway, and $73 \%$ in Spain (the lowest in Europe). Of the 410 companies that included some form of financial disclosure in their web sites, $80 \%$ (327 companies) used HTML in some form. It is important to mention that there are great differences in the type of financial information provided by companies 5 . Thus, the balance sheet is only disclosed by $59 \%$ of companies, the profit and loss account is disclosed by $59.5 \%$, the cash flow statement by $46 \%$, the notes to the accounts by $33 \%$, and the audit report by $28 \%$. It is interesting to consider that there are no countries where all companies provide all the statements. As far as the Spanish data, the balance sheet and the profit and loss account is disclosed by $73 \%$ ( 8 companies over 11 ), and the notes to the accounts and the audit report by $2 \%$ ( 2 over 11$)$.

The Spanish case was firstly studied by Sánchez (1999). He considered the information provided in 1997 by the 35 companies that form the IBEX 35 index, and showed that $63 \%$ of the companies had a web site, although only $32 \%$ of them included the annual accounts. The situation improved one year after, as Molero et al. (1999) indicated. They used the same sample in 1998 and provided higher percentages: $83 \%$ with web site and $45 \%$ include complete annual accounts. Regarding companies included in the IGBM (Indice General de la Bolsa de Madrid- General Index of the Madrid S. E.) $60 \%$ have a web site, while only $24 \%$ of them include the complete annual accounts. Finally using a sample of 215 companies listed on the Madrid S.E. , these authors showed that the average use of the Internet decreased significantly, arriving at lower percentages of $45 \%$ and $19 \%$ respectively. Gowthorpe and Amat (1999) considered a sample of 379 listed companies in 1998, providing rather lower percentages. However, these results have to be considered carefully because the sample included very different companies, not only typical financial institutions, such as banks, but also other institutions which invest in other listed companies (SIM and $\mathrm{SIMCAV}^{6}$ ), and the criteria to decide about the existence of

\footnotetext{
${ }^{5}$ See tables 5 and 6 (Lymer et al.1999, 53 and 55).

${ }^{6}$ SIM and SIMCAV are different types of companies quoted on the Spanish S.E. which invest in shares of other listed companies. They differ in the capital figure, fixed in the SIM, and variable, fluctuating when investors enter or leave the company in the SIMCAV.
} 
web site was the existence of a link with the Madrid $\mathrm{SE}^{7}$. A recent and interesting research is the one by Gandía (2001). He examined the web site of the 35 companies included in the IBEX 35 in April 2000, and found that only one company did not have web site. In addition he showed that $56 \%$ of the companies included complete annual accounts, but only $41 \%$ contained the audit report. He designed an index of quality of information based on the content, design and layout of the web site, but concluded that only 9 of the 35 companies under his study had a relatively good quality mark. In his opinion the Spanish companies are still not using the Internet as a mechanism to disseminate financial information, so they have to make an additional effort to use it.

In our view, all these studies confirm the tendency to use the Internet to communicate with financial users. In addition they indicate that the more selective is the sample, in terms of size and market capitalization, the more probable is that they have web site, and include financial information in it.

An aspect that it is really worrying is the discretionary use of the Internet to communicate financial information. In other words, in many cases even when companies include the annual accounts in their web sites, they are not complete. This generally affects to the notes to the accounts, that are absent or partially included, and to the audit report. The report by Lymer et al. (1999) indicates that in all the countries under analysis, companies are reluctant to include the audit report in their web sites. Gandía (2001) also insists on this problem, but there are other papers that have studied deeply this aspect.

In a pioneer US study, Debreceny and Gray (1996) found that the audit report was not generally included in the web site, even if the company included financial information (36\% included the report, while $68 \%$ had financial data), they showed that $61 \%$ contained the auditor's signature. A later study (Debreceny and Gray 1999), referred to 45 large and quoted companies in the UK, Germany and France, showed that all of them with only one exception had web site, $82 \%$ contained financial information, but only $23 \%$ included the audit report (although none of them included the auditor's signature). Another US study by Ettredge et al. (1999)

\footnotetext{
${ }^{7}$ As we have verified in our empirical analysis, there are many companies that have web site, although they do not communicated it to the Stock Exchange, so this criteria can give a biased view about the real attitude of companies towards the use of Internet.
} 
indicated that those companies with a qualified audit report due to going concern problems were more reluctant to include it in their web sites. This introduces serious doubts about the meaning of the lack of the audit report in the companys' web sites.

Table 1

Literature review on the use of Internet to disclose financial information

\begin{tabular}{|c|c|c|c|c|c|}
\hline YEAR & AUTHOR & $\begin{array}{l}\text { COUNTRY } \\
\text { SAMPLE }\end{array}$ & $\begin{array}{l}\text { WITH WEB } \\
\text { (1) }\end{array}$ & $\begin{array}{l}\text { WITH FIN. } \\
\text { INF. \%(1) }\end{array}$ & COMMENTS\% (1) \\
\hline 1996 & Petravick and Gillett & $\begin{array}{l}\text { USA } \\
150 \text { Fortune500 }\end{array}$ & $69 \%$ & $54 \%$ & $\begin{array}{l}31 \% \text { complete } \\
23 \% \text { un-complete }\end{array}$ \\
\hline 1996 & Louwers et al & Idem & $65 \%$ & $46 \%$ & \\
\hline 1997 & Gray and Debreceny & $\begin{array}{l}\text { USA } \\
50 \text { Fortune } 500\end{array}$ & $98 \%$ & $68 \%$ & $36 \%$ audit report \\
\hline 1997 & Lymer & $\begin{array}{l}\text { UK } \\
50 \text { largest quoted }\end{array}$ & $92 \%$ & $68 \%$ & $32 \%$ complete \\
\hline 1997 & Lymer and Tallberg & $\begin{array}{l}\text { Finland } \\
72 \text { quoted }\end{array}$ & $90 \%$ & $82 \%$ & $\begin{array}{l}11 \% \text { complete and } \\
71 \% \text { un-complete }\end{array}$ \\
\hline 1998 & Deller et al & $\begin{array}{l}\text { Germany } \\
\text { 30largest quoted }\end{array}$ & $87 \%$ & $83 \%$ & $\begin{array}{l}\text { Investors' } \\
\text { relationship }\end{array}$ \\
\hline 1999 & Craven and Marston & $\begin{array}{l}\text { UK } \\
200 \text { largest quoted }\end{array}$ & $74 \%$ & $71 \%$ & $\begin{array}{l}43 \% \text { complete } \\
28 \% \text { un-complete }\end{array}$ \\
\hline 1999 & Debreceny and Gray & $\begin{array}{l}\text { UK } \\
\text { France } \\
\text { Germany } \\
15^{*} \text { 3largest quoted }\end{array}$ & $\begin{array}{c}100 \% \\
93 \% \\
100 \%\end{array}$ & $\begin{array}{l}80 \% \\
78 \% \\
86 \%\end{array}$ & $23 \%$ audit. report \\
\hline 1999 & Deller et al & $\begin{array}{l}\text { USA } \\
\text { UK } \\
\text { Germany } \\
\text { 100FTSE,100S+P 100DAX) }\end{array}$ & $\begin{array}{l}95 \% \\
85 \% \\
76 \%\end{array}$ & $\begin{array}{l}97 \% \\
82 \% \\
73 \%\end{array}$ & $\begin{array}{l}92 \% \text { complete } \\
60 \% \text { complete } \\
42 \% \text { complete }\end{array}$ \\
\hline 1999 & Hedlin & $\begin{array}{l}\text { Sweden } \\
60 \text { quoted }\end{array}$ & $98 \%$ & $83 \%$ & $\begin{array}{l}\text { most of them } \\
\text { complete }\end{array}$ \\
\hline 1999 & $\begin{array}{l}\text { Pirchegger and } \\
\text { Wagenhofer }\end{array}$ & $\begin{array}{l}\text { Austria } \\
32 \text { largest quoted }\end{array}$ & $81 \%$ & & \\
\hline 1999 & Gowthorpe and Amat & $\begin{array}{l}\text { Spain } \\
379 \text { quotedIBEX } 35\end{array}$ & $\begin{array}{l}18,5 \% \\
74,2 \%\end{array}$ & & \\
\hline 1999 & Sánchez & $\begin{array}{l}\text { Spain } \\
\text { IBEX } 35\end{array}$ & $63 \%$ & $32 \%$ & \\
\hline 1999 & Molero et al & $\begin{array}{l}\text { Spain } \\
\text { IBEX } 35 \\
\text { IGBM } 120 \\
\text { 215quoted }\end{array}$ & $\begin{array}{l}83 \% \\
60 \% \\
45 \%\end{array}$ & $\begin{array}{l}72 \% \\
40 \% \\
34 \%\end{array}$ & $\begin{array}{l}45 \% \text { complete } \\
24 \% \text { complete } \\
19 \% \text { complete }\end{array}$ \\
\hline 1999 & Lymer et al. (IASC) & $\begin{array}{l}22 \text { countries } \\
660 \text { largest quoted }\end{array}$ & $86 \%$ & $62 \%$ & \\
\hline 2000 & BRRP (FASB) & $\begin{array}{l}\text { USA } \\
100 \text { Fortune500 }\end{array}$ & $99 \%$ & $93 \%$ & $\begin{array}{l}63 \% \text { complete } \\
6 \% \text { several GAAP }\end{array}$ \\
\hline 2001 & Gandía & $\begin{array}{l}\text { Spain } \\
\text { IBEX } 35\end{array}$ & $97 \%$ & $62 \%$ & $\begin{array}{l}56 \% \text { complete } \\
1 \% \text { audit report }\end{array}$ \\
\hline
\end{tabular}




\section{EMPIRICAL STUDY}

\subsection{Objectives}

As previously stated, the objective of this study is to analyze the use made by Spanish companies of the most visible of the Internet protocols, the web site, and their reasons for doing so. In addition to determining whether a company has its own web site or not, an analysis has been made of its content. To this end, we developed an index that considers some items of information directly related to the content and accessibility of the corporate web site (see the Appendix). To construct the index we took into account previous literature, such as Lymer et al. (1999) and FASB (2000), and certain private consultants specialized in investor relations, such as Conosco Ltd. and Addison, so we think it constitutes a quasicomplete set of the information necessary for the analysis and valuation of a company. In our index we value each item with 1 or 0 , depending on the information which was or was not included in the web site. The diversity in the number of items varies very much from one study into another one, in FASB (2000) 325 items were taken into account, while Ettredge et al. (1999) only consider 15 items. Our index considers the following aspects:

\section{Existence of a site dealing with investor relations}

2. Financial statements and intermediate accounting information. This item was decomposed in order to appreciate if the accounts were complete or non complete, the number of financial years covered, and the format in which they were presented (PDF, HTML, etc.).

3. Stock market information, such as prices market capitalization, volume traded, dividend, PER, etc. The existence of real time information was additionally valued.

4. Existence of reports of analysts, recommendations, valuations and reports of various different investment agencies and companies of analysis, together with those of the rating agencies. The number of reports was counted 
5. Corporate calendar.

6. Time series of financial data. The number of years was counted. In addition we also considered if the information was given in a processable format (such as Excel).

7. Relevant facts, (either directly or through links to the Stock Market Commission records). This item was decomposed in order to appreciate if the information was complete or not and the number of years covered, as well as the format in which they were presented (PDF, HTML, etc.).

8. Existence of a direct contact via electronic mail and mailing list.

9. Use of another language (English, French, German, or other).

10. Information on presentations to analysts, using the videoconference system or chats to enable make questions to the directors, or the executive responsible for investor relations.

11. Corporate information, such as the history of the company, strategies followed, major shareholders, etc. In particular we took into account the existence of information on the composition of the board, the CV's of its members, and the organization chart.

12. Industry information.

13. Press releases, provided either directly or through links.

14. Presentations to analysts at various levels. The existence of: graphics and images, additional comments, and summaries of the questions and answers arising in the course of these sessions were under consideration.

15. Information orientated towards the future, on the company's environmental policies, intangibles, intellectual capital, and similar aspects.

16. Employment of the cookie methodology to quantify the utilization of the website by various types of users, and to identify the particular information most frequently accessed. 


\subsection{Hypotheses}

For the purpose of explaining the corporate decisions relating to the utilization of the web site as a means of communication with those likely to be interested in the company, we have formulated six hypotheses mainly referred to the agency, signalling and political costs theories. These hypotheses, formulated in null terms, are presented in continuation.

H1: The use and scope of the information provided by a company via the Internet is independent of its size.

With respect to the scope or extent of voluntary disclosure of information, it is generally agreed that there exists a positive relationship between the size of the company and the scope of the information divulged. Cost-benefit analysis supports this proposition. Although the cost of preparing and disseminating information by the Internet is probably independent of size, and even non existent, as previously argued, this would not be true of the benefits, which should logically be greater the larger the company. Therefore in relative terms the costs of preparation and dissemination of the information are lower for larger companies, and this should create an incentive for greater disclosure.

Following Craven and Marston (1999), in this study we have utilized several variables as surrogates for company size: total assets, turnover, market capitalization, and total number of employees. As Hossain et al. (1994) indicate they could measure different aspects that are referred to the impact of size on the information policy of companies, such as competitive disadvantages, information production costs, and political costs.

Instead of using the original variables we employed logarithms in order to avoid problems derived from the asymmetry in the distribution of these variables.

$\mathrm{H} 2$ : The use and scope of the information provided by a company via the Internet is independent of company leverage.

Agency theory proposes that the greater the company's leverage, the higher will be the agency costs it incurs. This is due to the higher possibilities of 
transferring wealth from the creditors to the shareholders. By increasing the quantity of information disclosed, a company can reduce the agency costs and the possible conflicts between its owners and the creditors.

As in Giner (1997), the variable that we have utilized as a surrogate for the leverage is the debt ratio, calculated as debts divided by equity.

H3: The use and scope of the information provided by a company via the Internet is independent of return on equity .

Signalling theory suggests that the hypothesis put forward should be rejected, since only those companies with "good news" to report will be disposed to utilize voluntary mechanisms of information disclosure, and the absence of any information would be interpreted as a negative signal. In other words companies give signals, by way of financial information, to avoid the adverse selection problem. In addition from the perspective of the contractual theory, it could be assumed that managers of high profitable companies will be more prone to provide more detailed information, therefore the quantity of information disclosed may be linked with the profitability of the company. This can be seen as a mechanism to improve the image of the company, reinforce the directors' own job security and contribute to increase their remuneration.

Following Giner (1997) to proxy for "good news" and profitability we use the variable net profit divided by book value of equity (return on equity).

H4: The use and scope of the information provided by a company via the Internet is independent of whether or not the company's shares are quoted on overseas stock markets.

The fact of being listed on a foreign stock exchange may affect the quantity of information disclosed, given that the information requirements differ between countries. Furthermore, if a company hopes to obtain the potential benefits derived from a foreign quotation, such as the reduction in its cost of capital, the widening of its capital base and the increase in liquidity for its shares, it will have to make additional efforts in respect of investor relations, and be more proactive in its disclosure policy. Therefore, share quotation on foreign exchanges may be taken as a surrogate for the need for additional resources, and thus for potential agency costs. 
In this case, we have utilized a dichotomous variable, that takes the value 1 if the company is listed in foreign stock exchanges, as well as in the Madrid S.E., and 0 otherwise.

H5: The use and scope of the information provided by a company via the Internet is independent of the industry to which it belongs.

The political costs as well as other costs resulting from the loss of competitive advantages due to the disclosure of information may vary from one industry into another (Giner 1997). In addition it could be argued that companies in the same industry tend to adopt the same level of disclosure in order to avoid investors interpret the lack of information as a bad signal. In order to assess the effect of the industry to which the company belongs, we have defined three dichotomous variables, I1, I2 and I3, that indicate whether or not the activities of the company fall within the primary, secondary, and tertiary or services industries, respectively.

H6: The use and scope of the information provided by a company via the Internet is independent of its book to market ratio.

In this case, we assume that the greater the ratio the market capitalization of the company to the book value of equity, the greater will be the amount of intangibles not recorded by the accounts of the company. Therefore there will be a greater need to disclose information to enable the company to be properly valued.

\subsection{Sample}

The sample was based on the companies quoted on the Continuous Market (Mercado Continuo) of the Madrid Stock Exchange, and the period under study was the months of October and November $2000^{8}$, in total 144 companies. However due to the nature of our analysis we have focused on those companies that have a

\footnotetext{
${ }^{8}$ Although the data are about 18 months old, we still think that our results are valuable. Firstly because our main interest is to explain why companies use the Internet as an instrument to convey information to the users, and this does not depend, in principle, on the precise date of the data collection. Secondly we recognize that to have more updated data would be interesting to appreciate if companies have changed their attitude, but we compare with previous Spanish data to give an idea of the tendency of Spanish companies towards the use of the Internet. Finally the lack of timeliness of the data is a common problem to any empirical research.
} 
web site. Although companies listed on the Madrid S. E. have a direct link from the Stock Exchange web site to their corporate web sites, to access those that had not notified their addresses to the Exchange, we have utilized the LYCOS search engine, that is available at www.alltheweb.com, among others web sites. We found that 107 companies have web site, so this is the real sample in our study; of these companies, 88 are included in the IGBM, and 33 are included in the IBEX 35. So in fact most of the companies of this index formed by the 35 largest companies are included in our sample.

\subsection{Results}

\subsubsection{Time analysis}

In order to appreciate the evolution through time of the companies information policy in using the Internet, we have taken into account the results of the Spanish studies previously mentioned: Molero and Sevillano (1999) and Gandía (2001). As the first one considers the use of the Internet in September 1998, and the second in April 2000, both are good references to see the tendency up to October and November 2000, in having a web site and providing the annual accounts.

Figures 1 and 2 provide a summary of the results obtained in the three studies. In Figure 1, that includes data from the three studies, it may be clearly seen that there is an increasing tendency of companies to have their own web site. Regarding the companies included in the IBEX 35, in 1998 only about 83\% of companies have web site, while at the end of 2000 the percentage went up to $94 \%$. Regarding the inclusion of the annual accounts in the web, the percentages also show an increasing tendency, from $45 \%$ in 1998 up to $67 \%$ at the end of 2000. In addition looking at Figure 2, referred to companies in the IGBM, it can be observed that although the tendency is also increasing, the percentages are lower, which is due to the nature of the sample under analysis. The percentage of companies with web site was $60 \%$ in 1998 , and $78 \%$ at the end of 2000 , but only $24 \%$ and $50 \%$ respectively contained the annual accounts. As far as Gandía (2001) only focused on the IBEX 35 there are no data for this intermediate moment.

\footnotetext{
${ }^{9}$ It can be observed a reduction from April 2000, which can be due to problems in the web site of Acerinox and the merger of Continente and Pryca.
} 
Figure 1

Time Analysis (companies in the ibex35)

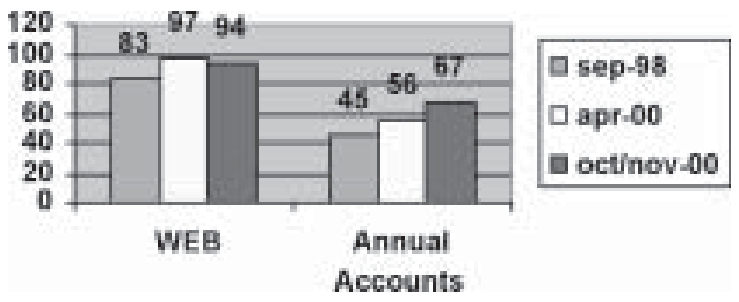

Annual Accounts : percentage of companies that include the annual accounts Web site: percentage of companies with website

Figure 2

Time analysis (companies in the IGBM)

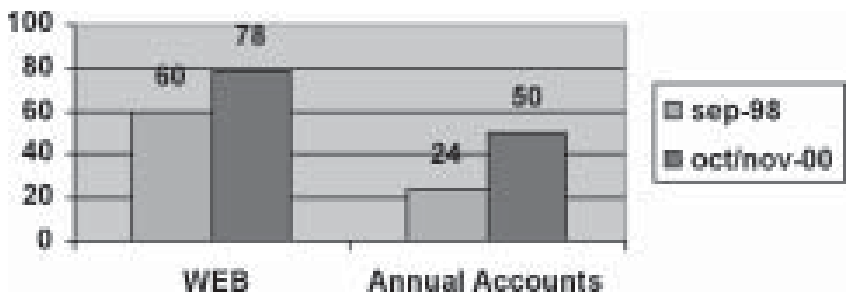

Web site: percentage of companies with website

Annual accounts : percentage of companies that include the annual account

\subsubsection{Industry analysis}

Regarding the relationship between industry type and the fact of having a web site and including the annual accounts, the previous evidence is not consistent. Lymer and Talberg (1997) found an industry effect associated with the disclosure 
of information through the Internet, while Craven and Marston (1999) did not find it. Table 2 includes selected information (annuals accounts and intermediate information) by industries regarding the disclosure through the web site. We have aggregated the different industries into three groups, primary, secondary and tertiary or service industry.

Table 2

Industry analysis

\begin{tabular}{|c|c|c|c|c|c|c|c|c|c|c|c|}
\hline \multirow[b]{3}{*}{ I1 } & \multirow[b]{3}{*}{45} & \multirow{2}{*}{\multicolumn{2}{|c|}{$\begin{array}{c}\text { Web } \\
\text { n } \\
\%\end{array}$}} & \multicolumn{2}{|c|}{$\begin{array}{c}\text { Annual } \\
\text { Accountsn }\end{array}$} & \multicolumn{2}{|c|}{$\begin{array}{l}\text { Complete Annnual } \\
\text { Accountsn }\end{array}$} & \multicolumn{2}{|c|}{$\begin{array}{l}\text { Intermediate } \\
\text { Informationn }\end{array}$} & \multicolumn{2}{|c|}{$\begin{array}{l}\text { Complete Intermediate } \\
\text { Informationn }\end{array}$} \\
\hline & & & & $\mathrm{n}$ & $\%$ & $\mathrm{n}$ & $\%$ & $\mathrm{n}$ & $\%$ & $\mathrm{n}$ & $\%$ \\
\hline & & 28 & 62 & 13 & 46 & 9 & 32 & 11 & 39 & 5 & 18 \\
\hline I2 & 28 & 23 & 82 & 10 & 43 & 9 & 39 & 10 & 45 & 4 & 18 \\
\hline I3 & 71 & 56 & 79 & 39 & 70 & 34 & 61 & 26 & 46 & 7 & 13 \\
\hline TOTAL & 144 & 107 & 74 & 62 & 58 & 52 & 49 & 47 & 44 & 16 & 15 \\
\hline
\end{tabular}

The primary industry shows the lowest percentage of companies with web site, $62 \%$, while the secondary one shows the highest $82 \%$, but the percentage of the tertiary industry, $79 \%$, is very close to the last one. However the financial information included in the web does not follow the same pattern. In particular, only the $43 \%$ of companies in the secondary industry include the annual accounts, being complete accounts only in the $39 \%$ of cases. Companies included in the tertiary industry are more prone to include the annual accounts, $70 \%$ of them do it, and $61 \%$ are complete accounts. As far as the intermediate information is referred, only $39 \%$ of the companies give the information in the primary industry, while the percentage goes up to $45 \%$ in the other two industries. In general terms it could be said that the service industry is the most interested in the use of the Internet as a way to provide accounting information to the users. This comes as no surprise as long as the banking companies, as well as the communications and new technologies companies are included in this group.

\subsubsection{Descriptive and explanatory analysis}

Table 3 reports the results of the descriptive analysis related to the content of Spanish companies' web sites, for the sample comprising all the companies quoted on the Continuous Market of the Madrid S.E., and for the two subsets, consisting 
of those belonging to the IBEX 35 and to the IGBM. It is valuable to mention that the more selective the sample, the greater the relative scope of the information disclosed in the web site. By way of example, the percentage of companies found to have a web site for the total sample is $74 \%$, whereas if we consider only those companies included in the IGBM and the IBEX 35, the percentages are $78 \%$ and $94 \%$, respectively.

Considering the largest sample, 58\% of the companies with a web site include the annual accounts, but only $49 \%$ of these give the complete accounts (balance sheet, profit and loss account, notes to the accounts, as well as audit report), providing them for a period of two years as an average; although there are companies that include six or even ten years data, most of them give just one or two years. As in the previous case, these percentages are higher when the sample is more selective: in the case of the IBEX 35, 67\% of the companies having a web site disclose the complete annual accounts. Although the amount of information increases when the sample is more restrictive the percentages are lower when the analysis is extended to the disclosure of more detailed information, except in specific cases such as the stock market information (share prices).

Regarding the largest sample, the intermediate information is shown by $44 \%$ of companies, but only $15 \%$ of them provide complete information. Stock exchange information is given by $61 \%$ of companies, although only $26 \%$ provide such information in real time. There are 12 cases (11\%) that give the analysts' reports, being 5 companies in the IBEX 35, and 11 in the IGBM. The average number of reports included in the web is 32 for the whole sample and 57 for companies included in the IBEX 35. Companies generally include time series of financial data, in fact $61 \%$ of them do it, and as an average they include 4 years data for comparison purposes, however there are only 3 companies that use a processable format.

The corporate calendar is only disclosed by 8 companies. Disclosure of relevant facts is given by 19 companies (18\%), although only 10 companies provide complete information (9\%). Companies tend to give their e-mail address in order to facilitate consults and contacts with the investors relations departments, $38 \%$ in the largest sample, $43 \%$ and $55 \%$ in the other two more restrictive samples (IGBM and IBEX). However it is interesting to remark that only 6 companies 
give the opportunity to the user to be included in a mailing list, in order to be permanently informed by the company, and none of them is in the IBEX 35.

The number of companies that give information in different languages is relatively high; 75 companies of the general sample do it in English, although the number goes down to 27 when the IBEX 35 is considered. Corporate information referred to the history of the company, and the composition of the board of directors is indicated by $90 \%$ of the largest sample (96 companies). The percentage of companies that give this information is very high, even if we consider the more restrictive samples, the IGBM and the IBEX 35, 94\% and 91\% respectively. However only one company, that is in the IBEX 35, indicates the curriculum vitae of the members of the directors' board.

Press releases are disclosed by $50 \%$ of the total sample of companies, but the percentage increases when a more restrictive sample is considered (56\% and $70 \%$ for the IGBM and the IBEX 35 sample respectively). Only 18 companies of the total sample (13 included in the IBEX 35) give the slides and other material used in the presentations to analysts; but the comments, questions and answers of these meeting are only provided by one company.

Information about intangibles is provided by $36 \%$ of the companies included in the largest sample (39 cases), however the percentages increase when the sample under analysis is more restrictive, $41 \%$ and $48 \%$ for the IBEX 35 and the IGBM samples respectively. 
Table 3

Information Contained in the Website

\begin{tabular}{|c|c|c|c|c|c|c|c|c|c|}
\hline & \multicolumn{3}{|c|}{ IBEX 35} & \multicolumn{3}{|c|}{ IGBM } & \multicolumn{3}{|c|}{ CONTINUOUS MARKET } \\
\hline & $\mathbf{N}$ & $\% 35$ & $\% 33$ & $\mathbf{N}$ & $\% 113$ & $\% 88$ & $\mathbf{N}$ & $\% 144$ & $\% 107$ \\
\hline $2 \mathrm{~N}^{\circ}$ COMPANIES & 35 & & & 113 & & & 144 & & \\
\hline WEB PAGE & 33 & 94.28 & 100 & 88 & 77.9 & 100 & 107 & 74.3 & 100 \\
\hline WEB SITE FOR INVESTOR & 27 & 77.14 & 81.82 & 52 & 46.00 & 59.00 & 54 & 37.5 & 50.46 \\
\hline RELATIONS & & & & & & & & & \\
\hline ANNUAL ACCOUNTS & 25 & 71.43 & 75.76 & 54 & 47.80 & 62.10 & 62 & 43.05 & 57.94 \\
\hline $\begin{array}{l}\text { COMPLETE ANNUAL } \\
\text { ACCOUNTS }\end{array}$ & 22 & 62.86 & 66.67 & 44 & 38.90 & 50.00 & 52 & 36.11 & 48.60 \\
\hline $\begin{array}{l}\mathrm{N}^{\circ} \text { OF YEARS } \\
\text { FORMAT OF ANNUAL } \\
\text { ACCOUNTS } \\
\text { 1. PDF } \\
\text { 2. HTML } \\
\text { 3. OTHER }\end{array}$ & $\begin{array}{c}23 \\
1 \\
1\end{array}$ & & & $\begin{array}{c}48 \\
5 \\
1\end{array}$ & & & $\begin{array}{c}56 \\
5 \\
1\end{array}$ & & \\
\hline $\begin{array}{l}\text { INTERMEDIATE } \\
\text { ACCOUNTS }\end{array}$ & 22 & 62.86 & 66.67 & 46 & 40.70 & 52.87 & 47 & 32.64 & 44.34 \\
\hline $\begin{array}{l}\text { COMPLETE INT. } \\
\text { ACCOUNTS }\end{array}$ & 6 & 17.14 & 18.18 & 15 & 13.27 & 17.24 & 16 & 11.11 & 15.09 \\
\hline $\begin{array}{l}\mathrm{N}^{\circ} \text { OF YEARS } \\
\text { FORMAT- INT. ACCOUNTS } \\
\text { 3. PDF } \\
\text { 4. HTML } \\
\text { 3. OTHERS }\end{array}$ & $\begin{array}{c}10 \\
7 \\
5\end{array}$ & & & $\begin{array}{c}2.3 \\
18 \\
21 \\
6\end{array}$ & & & $\begin{array}{c}2.2 \\
\\
18 \\
21 \\
7\end{array}$ & & \\
\hline $\begin{array}{l}\text { STOCK MKT } \\
\text { INFORMATION }\end{array}$ & 25 & 71.43 & 75.76 & 55 & 48.67 & 62.5 & 65 & 45.13 & 60.74 \\
\hline $\begin{array}{l}\text { REAL-TIME QUOTED } \\
\text { SHARE PRICE }\end{array}$ & 10 & 28.57 & 30.30 & 27 & 23.89 & 31.03 & 28 & 19.44 & 26.42 \\
\hline ANALYSTS' REPORTS & 5 & 14.29 & 15.15 & 11 & 9.73 & 12.64 & 12 & 8.33 & 11.32 \\
\hline $\mathrm{N}^{\circ}$ OF REPORTS & 57 & & & 31 & & & 32 & & \\
\hline CORPORATE CALENDAR & 6 & 17.14 & 18.18 & 6 & 5.31 & 6.90 & 8 & 5.55 & 7.55 \\
\hline $\begin{array}{l}\text { TIME SERIES OF } \\
\text { FINANCIAL DATA }\end{array}$ & 26 & 74.29 & 78.79 & 60 & 53.10 & 68.18 & 70 & 48.61 & 65.42 \\
\hline $\mathrm{N}^{\circ}$ OF YEARS & 4 & & & 4.2 & & & 4.2 & & \\
\hline $\begin{array}{l}\text { INFORM. IN } \\
\text { PROCESSABLE FORMAT }\end{array}$ & 3 & 8.57 & 9.09 & 3 & 2.65 & 3.45 & 3 & 2.08 & 2.83 \\
\hline RELEVANT FACTS & 11 & 31.43 & 33.33 & 18 & 15.93 & 20.68 & 19 & 13.19 & 17.92 \\
\hline COMPLETE REL. FACTS & 6 & 17.14 & 18.18 & 9 & 7.96 & 10.34 & 10 & 6.9 & 9.43 \\
\hline $\mathrm{N}^{\circ}$ OF YEARS & 3 & & & 4.1 & & & 3.9 & & \\
\hline $\begin{array}{l}\text { FORMAT OF REL. FACTS: } \\
\text { 1. PDF } \\
\text { 1. HTML } \\
\text { 3. OTHERS }\end{array}$ & $\begin{array}{l}4 \\
5 \\
2\end{array}$ & & & $\begin{array}{l}7 \\
9 \\
2\end{array}$ & & & $\begin{array}{l}7 \\
9 \\
3\end{array}$ & & \\
\hline ELECTRONIC MAIL & 18 & 51.42 & 54.54 & 38 & 33.63 & 43.18 & 41 & 28.47 & 38.32 \\
\hline MAILING LIST & - & & & 6 & 5.31 & 6.90 & 6 & 4.16 & 5.66 \\
\hline
\end{tabular}




\begin{tabular}{|c|c|c|c|c|c|c|c|c|c|}
\hline $\begin{array}{l}\text { INFORMATION IN } \\
\text { OTHER LANGUAGES } \\
\text { ENGLISH } \\
\text { FRENCH } \\
\text { GERMAN } \\
\text { OTHER }\end{array}$ & $\begin{array}{c}27 \\
2 \\
1 \\
4\end{array}$ & & & $\begin{array}{c}68 \\
9 \\
3 \\
16\end{array}$ & & & $\begin{array}{c}75 \\
10 \\
4 \\
17\end{array}$ & & \\
\hline $\begin{array}{l}\text { CORPORATE } \\
\text { INFORMATION }\end{array}$ & 30 & 85.71 & 90.91 & 83 & 73.45 & 94.31 & 96 & 66.66 & 89.72 \\
\hline COMPOSITION OF BOARD & 23 & 65.61 & 69.70 & 48 & 42.47 & 54.55 & 59 & 40.97 & 55.14 \\
\hline C. VITAE OF BOARD & - & 0 & 0 & 1 & 0.88 & 1.15 & 1 & 0.69 & 0.94 \\
\hline ORGANIZATION CHART & 21 & 60.00 & 63.64 & 33 & 29.2 & 37.5 & 44 & 30.55 & 41.12 \\
\hline C.V.'S OF DIRECTORS & 1 & 2.86 & 3.03 & 1 & 0.88 & 1.15 & 1 & 0.69 & 0.94 \\
\hline INDUSTRY INFORMATION & 7 & 20.00 & 21.21 & 10 & 8.85 & 11.49 & 10 & 6.94 & 9.43 \\
\hline PRESS RELEASES & 23 & 65.71 & 69.70 & 49 & 43.36 & 55.68 & 53 & 36.80 & 49.53 \\
\hline $\begin{array}{l}\text { PRESENTATIONS } \\
\text { TO ANALYSTS } \\
\text { GRAPHICS } \\
\text { COMMENTS } \\
\text { QUESTIONS \& ANSWERS }\end{array}$ & $\begin{array}{c}13 \\
1 \\
1\end{array}$ & & & $\begin{array}{c}17 \\
1 \\
1\end{array}$ & & & $\begin{array}{c}18 \\
1 \\
1\end{array}$ & & \\
\hline $\begin{array}{l}\text { INFORMATION ON } \\
\text { INTANGIBLES }\end{array}$ & 16 & 45.71 & 48.48 & 36 & 31.85 & 40.91 & 39 & 27.08 & 36.44 \\
\hline CHATS & 1 & 2.86 & 3.03 & 1 & 0.88 & 1.15 & 1 & 0.69 & 0.94 \\
\hline COOKIES & 3 & 8.57 & 9.09 & 7 & 6.19 & 8.05 & 7 & 4.86 & 6.60 \\
\hline
\end{tabular}

In spite of the different sampling dates and of the differences between the samples selected, it is considered of interest to compare our results with Deller, et al. (1999), covering the United States, the United Kingdom and Germany. Their study considers the 100 largest companies of the S\&P index, the FTSA index and the DAX index respectively and the data were collected in January 1998, that is about 3 years prior to our study. This comparison reveals that the presence of web sites in the case of Spain, and taking as the sample those companies included in the IBEX 35, is similar to that of the USA (95\%) and higher than in the UK $(85 \%)$ and Germany (76\%). Taking the companies included in the IGBM or the Continuous Market as the references, Spain would be close to the German level but below that of the UK. Independently of which Spanish sample is utilized, the disclosure of complete annual accounts is always higher than the German level; but considering only those companies included in the IBEX 35 (67\%), Spain is situated between the USA $(92 \%)$ and the UK $(60 \%)$. Nevertheless it is important to consider the lag in the Spanish data that may explain the differences. In fact Molero et al. (1999) report that, in 1998, 45\% of the IBEX 35 companies with web site included complete annual accounts, while only $24 \%$ of the IGBM 
companies did it (and 19\% of a largest sample), what locates Spain in a very different position.

In order to test the hypotheses that explain the company decisions about the web site disclosure, we have devised an index of disclosure. For the quantification of this index, all the aspects analyzed and previously indicated have been considered. The preparation of such indices of disclosure is a fairly common practice is studies of voluntary disclosure (e.g. Chow and Won-Boren, 1987), and also in previous studies dealing with information issued through the Internet (Pirchegger and Wagenhofer, 1999 and Gandía, 2001). The main problem associated with the utilization of a combined measure of disclosure lies in deciding the weighting to assign to each of the components. The solution usually adopted is not to weight the different items, so as to avoid the subjectivity involved in selecting a specific weight for the components analyzed (Giner, 1997). To be consistent with this and with the other studies analyzing the disclosure of financial information by the Internet, we have weighted as 1 all the elements related to the content, and as 0.25 all those related to accessibility, navigability and utilization of the advantages provided by the web methodology, such as: Electronic mail, Mailing lists, Cookies, processable Format, Chats, Video conferencing, etc. ${ }^{10}$

Having applied the index to the companies that possess a web site ${ }^{11}, 107$ observations, we have studied the correlations of the value of the index with the independent variables previously defined. Considering the matrix of correlations presented in Table 4, the following results can be inferred:

- There is a significant association between all the variables employed as surrogates of the company size factor and the index of disclosure value

\footnotetext{
${ }^{10}$ The items which have been weighted with one to obtain the index have been the following: Existence of Full Accounts multiplied by number of years, Interim Accounts multiplied by number of years, existence of stock market information, prices on real time, Analyst Reports, Corporate Calendar, Financial Time Series, Relevant Reports, Composition of the Board, CV of the members of the Board, Industry Information, Press Releases, Information provided to financial analysts on general meetings, information about intellectual capital, orientated towards the future, etc. On the other hand, other items have been weithed with 0.25 like the following: processable format on financial time series, electronic mail, mailing list, conference call, chats andy cookies.

${ }^{11}$ In addition we have analyzed the reasons that explain the existence of a corporate web site page, and the inclusion of the annual accounts in the page. But due to space limitrations, these results are not provided here, although we can say that they are consistent with the reasons that explain the amount of information disclosed and reported here.
} 
- No significant association exists between the values of the index and the debt ratio.

- Return on equity and industry do not explain the amount of information disclosed

- Lastly, there is a significant association between the scope of the information disclosed and the fact of having a share quote on a foreign exchange.

Table 4

Correlation Matrix

\begin{tabular}{|c|c|c|c|c|c|c|c|c|c|c|}
\hline $\begin{array}{l}\text { Pearson } \\
\text { Spearman }\end{array}$ & $\begin{array}{l}\text { Log } \\
\text { Assets }\end{array}$ & $\begin{array}{l}\text { Log } \\
\text { Turnov. }\end{array}$ & Employees & $\begin{array}{l}\text { Log } \\
\text { Market } \\
\text { Capital. }\end{array}$ & $\begin{array}{l}\text { Debt } \\
\text { Ratio }\end{array}$ & $\begin{array}{l}\text { Return } \\
\text { on equity }\end{array}$ & I1 & I2 & I3 & $\begin{array}{l}\text { Foreign } \\
\text { listing }\end{array}$ \\
\hline Log Assets & 1 & & & & & & & & & \\
\hline $\begin{array}{l}\text { Log } \\
\text { Turnover }\end{array}$ & $\begin{array}{l}0.784^{* *} \\
0.768^{* *}\end{array}$ & 1 & & & & & & & & \\
\hline Employees & $\begin{array}{l}0.597^{* * *} \\
0.686^{* *}\end{array}$ & $\begin{array}{l}0.607 \text { ** } \\
0.856^{* *}\end{array}$ & 1 & & & & & & & \\
\hline $\begin{array}{l}\text { Log. Market } \\
\text { Capitalization }\end{array}$ & $\begin{array}{l}0.870^{* *} \\
0.839 \text { ** }\end{array}$ & $\begin{array}{l}0.747^{* *} \\
0.738^{* * *}\end{array}$ & $\begin{array}{l}0.576^{* *} \\
0.664 * *\end{array}$ & 1 & & & & & & \\
\hline Debt Ratio & $\begin{array}{l}0.316^{* *} \\
0.591^{* *}\end{array}$ & $\begin{array}{l}0.189 * \\
0.479 * *\end{array}$ & $\begin{array}{l}0.177^{*} \\
0.450^{* *}\end{array}$ & $\begin{array}{l}0.248 * * \\
0.398 * *\end{array}$ & 1 & & & & & \\
\hline $\begin{array}{l}\text { Return on } \\
\text { equity }\end{array}$ & $\begin{array}{l}-0.085 \\
0.071\end{array}$ & $\begin{array}{l}-0.087 \\
0.126\end{array}$ & $\begin{array}{l}-0.028 \\
0.169\end{array}$ & $\begin{array}{l}-0.059- \\
0.302\end{array}$ & $\begin{array}{l}0.867^{\text {** }} \\
0.119\end{array}$ & 1 & & & & \\
\hline I1 & $\begin{array}{l}-0.129 \\
-0.116\end{array}$ & $\begin{array}{l}0.096 \\
0.082\end{array}$ & $\begin{array}{l}-0.121 \\
-0.058\end{array}$ & $\begin{array}{l}-0.059 \\
0.302\end{array}$ & $\begin{array}{l}-0.213^{*} \\
-0.197^{*}\end{array}$ & $\begin{array}{l}0.096 \\
-0.004\end{array}$ & 1 & & & \\
\hline I2 & $\begin{array}{l}-0.010 \\
-0.011\end{array}$ & $\begin{array}{l}0.169^{*} \\
0.142\end{array}$ & $\begin{array}{l}0.031 \\
0.153\end{array}$ & $\begin{array}{l}-0.057 \\
-0.079\end{array}$ & $\begin{array}{l}-0.005 \\
0.057\end{array}$ & $\begin{array}{l}-0.060 \\
0.067\end{array}$ & $\begin{array}{l}-0.331 * * \\
-0.331 * *\end{array}$ & 1 & & \\
\hline I3 & $\begin{array}{l}0.129 \\
0.118\end{array}$ & $\begin{array}{l}-0.202^{*} \\
-0.188^{*}\end{array}$ & $\begin{array}{l}0.089 \\
-0.066\end{array}$ & $\begin{array}{l}0.185^{*} \\
0.212^{*}\end{array}$ & $\begin{array}{l}0.204 \\
* 0.141\end{array}$ & $\begin{array}{l}-0.043 \\
0.067\end{array}$ & $\begin{array}{l}-0665^{* *} \\
-0.665^{* *}\end{array}$ & $\begin{array}{l}-0.485^{* *} \\
-0.485 * *\end{array}$ & 1 & \\
\hline $\begin{array}{l}\text { Foreign } \\
\text { listing }\end{array}$ & $\begin{array}{l}0.519^{* *} \\
0.449^{* *}\end{array}$ & $\begin{array}{l}0.501^{* *} \\
0.466^{* *}\end{array}$ & $\begin{array}{l}0.461^{* *} \\
0.443^{* *}\end{array}$ & $\begin{array}{l}0.629 \text { ** } \\
0.565^{* *}\end{array}$ & $\begin{array}{l}0.126 \\
0.312^{* *}\end{array}$ & $\begin{array}{l}-0.023 \\
0.143\end{array}$ & $\begin{array}{l}-0.083 \\
-0.083\end{array}$ & $\begin{array}{l}0.043 \\
0.043\end{array}$ & $\begin{array}{l}0.043 \\
0.043\end{array}$ & 1 \\
\hline Index & $\begin{array}{l}0.507^{* *} \\
0.462^{* *}\end{array}$ & $\begin{array}{l}0.437^{* *} \\
0.402 * *\end{array}$ & $\begin{array}{l}0.330 \text { ** } \\
0.335 \text { ** }\end{array}$ & $\begin{array}{l}0.518^{* *} \\
0.479^{* *}\end{array}$ & $\begin{array}{l}0.150 \\
0.328\end{array}$ & $\begin{array}{l}-0.073 \\
0.051\end{array}$ & $\begin{array}{l}-0.130 \\
-0.141\end{array}$ & $\begin{array}{l}-0.043 \\
-0.043\end{array}$ & $\begin{array}{l}0.087 \\
0.097\end{array}$ & $\begin{array}{l}0.747^{\text {*** }} \\
0.337^{* * *}\end{array}$ \\
\hline
\end{tabular}

Table 5 includes the descriptive statistics of the variables included in our analysis.

Table5

Descriptive statistics of the independent variables

\begin{tabular}{|l|l|c|c|c|c|c|c|c|c|c|}
\hline & $\begin{array}{c}\text { Log of } \\
\text { Assets }\end{array}$ & $\begin{array}{c}\text { Log of } \\
\text { Turn-over }\end{array}$ & Employ. & $\begin{array}{c}\text { Log of } \\
\text { Market } \\
\text { Capitaliz. }\end{array}$ & $\begin{array}{c}\text { Debt } \\
\text { Ratio }\end{array}$ & $\begin{array}{c}\text { Return } \\
\text { on equity }\end{array}$ & $\begin{array}{c}\text { Foreign } \\
\text { listing }\end{array}$ & I1 & I2 & I3 \\
\hline MEAN & 11.612 & 10.711 & 7208.83 & 11.221 & 2.254 & 0.201 & 0.180 & 0.312 & 0.194 & 0.493 \\
\hline $\begin{array}{l}\text { MEDIAN } \\
\text { STANDARD }\end{array}$ & 11.349 & 10.603 & 1600.00 & 11.179 & 1.541 & 0.119 & 0.000 & 0.000 & 0.000 & 0.000 \\
\hline DEVIATION & 1.890 & 1.848 & 16818.5 & 1.841 & 11.233 & 0.683 & 0.386 & 0.465 & 0.397 & 0.501 \\
\hline ASYMMETRY & 0.503 & -0.159 & 4.720 & 0.344 & -8.937 & 9.985 & 1.678 & 0.818 & 1.560 & 0.028 \\
\hline KURTOSIS & 0.593 & 1.083 & 26.473 & 0.289 & 97.804 & 107.223 & 0.829 & -1.351 & 0.441 & -2.028 \\
\hline
\end{tabular}


Finally a multiple regression analysis was performed. In order to consider simultaneously all the variables and to avoid problems of multicolinearity, we have only included two industries variables and only one size variable. We used the logarithm of the market capitalization since it showed the closest individual association with the disclosure index. The dichotomous variable referred to the foreign listing was eliminated, due to the high association of this with the other variables. So our model is:

$$
\mathrm{I}=\mathrm{a} 0+\mathrm{a} 1 \cdot \mathrm{MC}+\mathrm{a} 2 \cdot \mathrm{D}+\mathrm{a} 3 \cdot \mathrm{ROE}+\mathrm{a} 4 \cdot \mathrm{BM}+\mathrm{a} 5 \mathrm{I} 2+\mathrm{a} 6 \cdot \mathrm{I} 3+\mathrm{e}
$$

Where:

$\mathrm{I}=$ disclosure index, $\mathrm{MC}=\log$ arithm of market capitalization, $\mathrm{D}=$ debt to equity ratio

$\mathrm{ROE}=$ return on equity ratio, $\mathrm{BM}=$ book to market ratio, $\mathrm{I} 2=$ secondary industry, $\mathrm{I} 3$ = tertiary industry

The model presented in Table 6 shows that the only significant variable is size. At first sight, it may be surprising that the ratio book to market does not have explanatory capacity. In our view this could be due to several reasons, such as the preference of private channels to disclose information about intangibles, with the objective of avoiding or at least reducing the competitive disadvantages.

Table 6

Linear regression between the index of disclosure and various explanatory factors

\begin{tabular}{|c|c|c|c|}
\hline VARIABLE & COEFFICIENT & $\mathbf{T}$ & Sig \\
\hline Constant & -8.273 & -3.133 & 0.002 \\
\hline Log. MC & 1.409 & 5.982 & 0.000 \\
\hline I2 & 0.779 & 0.793 & 0.430 \\
\hline I3 & -0.256 & -0.299 & 0.766 \\
\hline 2.1.1.1.1.1.1.D & -0.115 & -1.434 & 0.156 \\
\hline ROE & -3.896 & -0.686 & 0.495 \\
\hline BM & 0.128 & 0.809 & 0.421 \\
\hline $\mathbf{R}^{2}$ & 0.332 & & \\
\hline $\mathbf{F}$ & 8.294 & & \\
\hline Sig & 0.000 & & \\
\hline
\end{tabular}


The model is: $I=a_{0}+a_{1} M C+a_{2} D+a_{3} R O E+a_{4} B M+a_{5} I 2+a_{6} I 3+e$. where: $I=$ disclosure index. $M C=$ logarithm of market capitalization. $D=$ debt to equity ratio $R O E=$ return on equity ratio. $B M=$ book to market ratio. $I 2=$ secondary industry. $I 3$ = tertiary industry

These results are partially consistent with previous studies. In particular Ausbagh et al. (1999) and Ettredge et al. (1999) have analysed the business attributes of US companies that have a web site. They conclude that size, profitability and the need to obtain external funds have a positive relationship with the existence of a company web site. In the UK, Craven and Marston (1999) also showed that size is related to the existence of a web site. In addition they concluded that the existence of financial information in the web site, as well as the amount of financial information included there are also related to size. However, and also consistently with our results, they did not find any relationship with industry. Finally Pirchegger and Wagenhofer (1999) indicated that the web site quality increases with size and the shareholders dispersion. This last reason could be due to the higher profits derived from the information disclosure in this type of companies, compared with companies with shareholder concentration. In fact the less concentrated is the companies ownership, the more shareholders exist, who are potentially benefited due to the information disclosed through the Internet.

\section{CONCLUSIONS}

The future of the disclosure of company information by the Internet cannot be restricted to the disclosure of exclusively financial information. Both the recommendations and guides issued by the professional accounting bodies, and the requirements of the various different users of company information, indicate that this medium of communication contributes to improve and widen traditional financial communication, based on the full annual reports and on intermediate accounting information. This improvement will have to take the form not only of an increased quantity of information (information that is more qualitative than quantitative, more orientated to the future than to the past and present of the company), but also in terms of opportunity of access, extending its availability to new users. This means making publicly-available information previously reserved for sophisticated or privileged users, permitting interactivity, and increasing the frequency in order to transform the periodical reporting into a continuous one. 
The new technologies of information, and in particular the web, are an ideal instrument for this development. The challenge to the professional bodies is to define codes of conduct, to standardize contents, and to dictate rules and recommendations that will help to guarantee their reliability and comparability of information. Considering the disappearance of borders in the transfer of information, this process of regulation will need to be international in character.

Although the level of disclosure of financial information through the Internet by Spanish companies is still low, is increasing gradually over time. Greater disclosure through this communication channel is related to company size. Although Spain is in the early stages of developing the possibilities offered by the Internet, we are nevertheless not significantly behind the degree of utilization in other countries such as the USA and the UK, a couple of years ago. However, at the moment the advantages to be gained from using the new technologies to widen the audience of people interested in company information are considered strictly limited in the case of Spain. Although 58\% of companies in the continuos market (our largest sample), and 76\% of the IBEX 35 companies (the smallest sample) that have a web site include the annual accounts, the percentages decrease when detailed and timely information is considered, such as intermediate information, analysts' reports, presentation to analysts, relevant events, or information on intangibles.

In our opinion, an interesting line of research is that aimed at understanding how new technologies are changing the habits of corporate managers in the field of investor relations generally. Equally, it would be useful to investigate how these new channels of communication might improve the comparability and relevance of the information disclosed, in the international panorama, given the very heterogeneous practices that are currently encountered, and how to guarantee the quality of the information, given the difficulties that the new technologies present for conventional auditing of accounts.

\section{REFERENCES}

ASHBAUGH, H., JOHNSTONE, K.M. and WARFIELD, T.D. (1999): "Corporate reporting on the internet”. Accounting Horizons. Vol. 13. Pp. 241-257. 
BEATTIE, V. (1999): Business Reporting: The Inevitable Change. The Institute of Chartered Accountants of Scotland. Edinburgh.

CHOW, C.W. and WONG-BOREN, A. (1987): "Voluntary Financial Disclosure by Mexican Corporations". Accounting Review. Vol. 62:3. Pp. 533-541.

CRAVEN, B.M. and MARSTON, C.L. (1999): "Financial reporting on the internet by leading UK companies". European Accounting Review. Vol. 8:2. Pp. 321-333.

DEBRECENY, R. and GRAY, G. (1999): "Financial reporting on the internet and the external audit". European Accounting Review. Vol. 8:2. Pp. 335-350.

DELLER, D., STUBENRATH, M. and WEBER, C. (1998): "Investor relations and the internet: background, potential application and evidence from the USA, UK and Germany". Communication presented to the 21st Annual Congress of the European Accounting Association. Antwerp. Belgium. April.

http://intacc.wiwi.uni-frankfurt.de/papers/Internet_Inv_Rel.html-30.10.98.

DELLER, D., STUBENRATH, M. and WEBER, C. (1999): "A Survey of the survey of the internet for investor relations in the USA, the UK and Germany". European Accounting Review. Vol. 8:2. Pp. 351-364.

EDWARDS, P. and R. A. SMITH (1996): "Competitive disadvantage and voluntary disclosures: the case of segmental reporting”, British Accounting Review, Vol 28. Pp155-172.

ETTREDGE, M., RICHARDSON, V.J., and SCHOLZ, S. (1999): Determinants of voluntary dissemination of financial data at corporate web sites, Working paper, University of Kansas.

FASB (2000): Business Reporting Research Project. Electronic Distribution of Business Reporting Information. Financial Accounting Standards Board. http:// www.rutgers.edu/Accounting/raw/fasb/brrppg.html.

GANDIA, JL. (2001): La divulgación de información financiera en la era digital. Asociación Española de Contabilidad y Administración de Empresas, Madrid.

GINER, B. (1997): «The influence of company characteristics and accounting regulation on information disclosed by Spanish firms" The European Accounting Review, Vol6:1 Pp. 45-68 
GOWTHORPE, C. and AMAT, O. (1999): "External reporting of accounting and financial information via the internet in Spain". European Accounting Review. Vol. 8:2. Pp. 365-372.

GRAY, G.L. and DEBRECENY, R. (1997): "Corporate reporting on the internet: opportunities and challenges". 7th Asian-Pacific Conference on International Accounting Issues. Bangkok.

HEDLIN, P. (1999):" The internet as a vehicle for investor relations: The Swedish case". European Accounting Review. Vol.8:2. Pp. 373-382.

HOLTHAUSEN, R.W. and LEFTWICH, R.W. (1983): "The economic consequences of accounting choice", Journal of Accounting and Economics, Vol. 5. Pp. 77-117.

HOSSAIN, M.M.; PERERA, H.B. and RAHMAN, A.R. (1995): "Voluntary Disclosure in the Annual Reports of New Zealand Firms". Journal of International Financial Management and Accounting. Vol. 6:1. Pp. 69-87.

ICAEW (1998b): The 21st Century Annual Report. The Institute of Chartered Accountants in England and Wales. London.

JENSEN, M.C. and W.H. MECKLING (1976):"Theory of the firm: Managerial Behavior, Agency Costs and Ownership Structure". Journal of Financial Economics. Vol.3. October: 305-360.

LOUWERS, T., PASEWARK, W. and TYPPO, E. (1996): "The Internet: changing the way corporations tell their story". CPA Journal. Vol. 66:11. Pp. 24-28.

LYMER, A. (1997): "The use of internet for corporate reporting- a discussion of the issues and survey of current usage in the UK". Journal of Financial Information Systems. http://www.shu.ac.uk/jfis.

LYMER, A. (1999): "The Internet and the future of corporate reporting in Europe". European Accounting Review. Vol. 8:2. Pp. 289-301.

LYMER, A. and TALLBERG, A. (1997): "Corporate reporting and the internet- a survey and commentary on the use of the WWW in corporate reporting in the UK and Finland". 20th Congress of the European Accounting Association. Graz. Austria. http://www.summa.org.uk/SUMMA/corp/papers/papers.html-30.10.98.

LYMER, A., DEBRECENY, R., GRAY, G.L. and RAHMAN (1999): Business Reporting on the internet. http://www.iasc.org.uk/frame/cen3_26.htm 
MOLERO, J.J., PRADO, A. and SEVILLANO, F.J. (1999). The presentation of financial statements through the internet: analysis of the most significant companies in Spain. 22th Congress of the European Accounting Association. Bordeaux. France.

PETRAVICK, S. and GUILLET, J. (1996). "Financial reporting on the World Wide Web”. Management Accounting. 78. July. Pp. 26-29.

PIRCHEGGER, B. and WAGENHOFER, A. (1999): "Financial Information on the internet: a survey of the homepages of Austrian Companies". European Accounting Review, Vol. 8:2 Pp. 383-393.

SANCHEZ, M. (1999): La Memoria como cuenta anual. Un estudio empírico. Doctoral Thesis, University of Sevilla.

WAGENHOFER, A. (1990): "Voluntary Disclosure with a Strategic Opponent", Journal of Accounting and Economics, Vol12: 341-363. 